\title{
Mediastinitis after cardiac surgery: risk factors and our vacuum-assisted closure results
}

\author{
Abdul Kerim Buğra ${ }^{1}$, Safa Göde${ }^{1}$, Aytül Buğra² ${ }^{2}$ Sefa Eltutan ${ }^{1}$, Zeinab Arafat ${ }^{3}$, Onur Şen ${ }^{1}$, Vedat Erentuğ ${ }^{1}$ \\ ${ }^{1}$ University of Health Sciences, Mehmet Akif Ersoy Thoracic and Cardiovascular Surgery Training and Research \\ Hospital, Istanbul, Turkey \\ ${ }^{2}$ Council of Forensic Medicine, Histopathology Department, Istanbul, Turkey \\ ${ }^{3}$ Department of Cardiovascular Surgery, University of Health Sciences, Bağcılar Training and Research Hospital, Istanbul, Turkey
}

Kardiochirugia i Torakochirurgia Polska 2021; 18 (4): 195-202

\begin{abstract}
Introduction: Mediastinitis after cardiac surgery is a rare complication, but with high morbidity and mortality.

Aim: To determine its risk factors and to investigate the efficacy of vacuum-assisted closure (VAC).

Material and methods: Nine thousand one hundred sixty cases of patients who underwent cardiac surgery during 2010-2017 were reviewed retrospectively. One hundred and twenty-seven patients, the case group, were treated by VAC. Three hundred cases with no diagnosis of mediastinitis were selected as the control group. Both groups' clinical and demographic characteristics, preoperative variables, and postoperative follow-up parameters were compared. Factors affecting treatment were analyzed. Results: We found that the presence of diabetes mellitus, bilateral internal thoracic artery and intra-aortic balloon pump usage are independent risk factors for the development of mediastinitis $(p<0.05)$. It was found that $74 \%$ of tissue cultures were positive and the most common detected organism was Staphylococcus. It was found that many perioperative parameters had a significant effect on the duration of treatment $(p<0.05)$. However, regression analysis revealed that bacterial growth was the only independent variable in prolonging the treatment period.

Conclusions: We believe that the establishment of perioperative blood glucose regulation, patient selection to use bilateral internal thoracic artery grafts, and maximum attention to sepsis and antisepsis rules in patients who need mechanical support devices such as intra-aortic balloon pump, will significantly reduce the development of mediastinitis. Since we could not find an independent risk factor for the duration of VAC treatment other than culture growth, we think that VAC therapy is successful and safe in the treatment of mediastinitis and should be used more widely.
\end{abstract}

Key words: mediastinitis, vacuum-assisted closure, risk factors, cardiac surgery.

\section{Introduction}

Mediastinitis seen after cardiac surgery is rare but is considered as a serious complication. It increases the length of postoperative hospital stay, mortality and morbidity. The incidence after median sternotomy is in the range of $1-2 \%$ [1]. Mortality was in the range of $2-8 \%$. However, the mortality rate of mediastinitis due to comorbid conditions reaches $14 \%$ [2].

According to the Centers for Disease Control and Prevention (CDC) definition of surveillance for specific infections, mediastinitis must meet at least one of the following criteria [3]:

1. The patient has pathogen(s) identified from mediastinal tissue or fluid by a culture or non-culture based microbiologic testing method which is performed for the purposes of clinical diagnosis or treatment.
2. The patient has evidence of mediastinitis on gross anatomic or histopathologic examination.

3. The patient has at least one of the following signs or symptoms:

- Fever $\left(>38.0^{\circ} \mathrm{C}\right)$,

- Chest pain (with no other recognized cause),

- Sternal dehiscence,

And at least one of the following:

- Purulent drainage from the mediastinal area,

- Mediastinal widening in imaging test.

Although mediastinitis is a surgical site infection, risk factors need to be modified to prevent this complication. The results obtained in the studies conducted for this purpose vary according to the demographic data and the designs of the studies. Many dependent and independent risk factors have been identified [1, 2, 4-10].

Address for correspondence: Abdul Kerim Buğra MD, University of Health Sciences, Mehmet Akif Ersoy Thoracic and Cardiovascular Surgery Training and Research Hospital, Istanbul, Turkey, e-mail: a.kerim@gmail.com Received: 4.05.2021, accepted: 3.08.2021. 
Mediastinitis treatment covers a wide range from simple extended antibiotic treatment to full sternectomy and major plastic procedures [11]. Conventional treatment includes repeated wound irrigations, debridements and various sternal reconstruction techniques with antibiotics and disinfectants [12-14]. The high mortality and morbidity rates of conventional mediastinitis therapies have led to an alternative treatment over time. The superiority of vacuum-assisted closure (VAC) in mediastinitis treatment has been demonstrated by studies and meta-analysis over time $[15,16]$.

VAC provides simultaneous chest stabilization by isolating the wound while continuously removing the exudate from it. It induces granulation tissue formation by providing a constantly moist environment and induces wound healing by increasing blood flow from surrounding tissue [17]. Reducing tissue edema also regulates capillary permeability and osmolarity by preventing compartment syndrome occurring at the wound edges [18]. Also, studies report decreasing bacterial load within the wound [19].

VAC treatment can be repeated in mediastinitis cases until the sternal reconstruction stage. This reconstruction may be possible with sternum re-wiring or muscle skin flaps [14]. It has been observed that VAC treatment decreases mortality and recurrent mediastinitis when applied as a bridge therapy to flap surgery [20].

\section{Aim}

In our study, we aimed to determine risk factors according to our demographic structure and examine our VAC treatment results.

\section{Material and methods}

The study was approved by the Ethical Committee of Health Sciences University Mehmet Akif Ersoy Training and Research Hospital according to the decision dated 08/06/2018 and numbered 2018/26.

In this study, 9160 cases of patients who underwent cardiac surgery with median sternotomy between January 2010 and December 2017 in Istanbul Mehmet Akif Ersoy Thoracic and Cardiovascular Surgery Training and Research Hospital, Department of Cardiovascular Surgery were reviewed retrospectively. In this period, 427 (69.3\%) $(n=296)$ male and $30.7 \%(n=131)$ female patients with mean age $60.81 \pm 10.47$ were included in the study. Information about the cases was obtained from hospital archive files and electronic medical record system.

\section{Patient selection}

Our study was divided into two groups. The mediastinitis group included 127 patients diagnosed with mediastinitis who were treated with the VAC technique. By evaluating risk factor analysis data in similar literature, the sample size was calculated with $80 \%$ power and 5\% type-1 error. The control group was chosen among eligible patients with no evidence of surgical site infection, and who had not undergone minimally invasive open-heart surgery by standard surveillance and chart review. The control group was matched 2: 1 per case and identified by using a random number table using \pm 5 sorted by surgery date (within the same year), gender and age.

Superficial surgical site infections, patients under 18 years of age who had undergone cardiac surgery, patients who had undergone minimally invasive open-heart surgery, patients who had undergone cardiac surgery in other centers and then received mediastinitis treatment in our center were excluded from our study.

Between the two groups preoperative (age, gender, body surface area (BSA), ejection fraction (EF), smoking, diabetes mellitus (DM), hypertension, chronic obstructive pulmonary disease, presence of other comorbid systemic diseases, hematocrit $(\mathrm{Htc})$, hemoglobin $(\mathrm{Hb})$, white blood cell count, platelets, calcium, mean platelet volume (MPV), C-reactive protein (CRP), sedimentation, glycated hemoglobin $\left(\mathrm{HbA}_{1 \mathrm{c}}\right)$, cholesterol, and vitamin $\mathrm{B}_{12}$ levels), intraoperative (type of surgery, surgical timing, presence of redo surgery, internal thoracic artery (ITA), bilateral ITA (BITA) use, total pump time (TPT), aortic cross clamp time, bone-wax use, EuroSCORE) and postoperative (Inotropic support use, intra-aortic balloon pump (IABP), intensive care unit stay, blood product use, amount of drainage, length of hospital stay, presence of mortality) parameters were compared in terms of significant difference. The effects of perioperative parameters on the mediastinitis treatment were evaluated in patients diagnosed with mediastinitis.

\section{Statistical analysis}

Statistical analysis was performed to determine the independent risk factors in the development of mediastinitis with the parameter data that differed significantly between the two groups, and to show whether it was effective with respect to VAC treatment time and mortality.

Number Cruncher Statistical System (NCSS) 2007 (Kaysville, Utah, USA) was used for statistical analysis. Descriptive statistical methods (mean, standard deviation, median, first quarter, third quarter, frequency, percentage, minimum, maximum) were used to evaluate the study data. The suitability of the quantitative data for normal distribution was tested by the Shapiro-Wilk test and graphical analysis. The independent groups $t$ test was used for comparison between two groups of quantitative variables showing normal distribution, and the Mann-Whitney $U$ test was used for comparison between two groups of quantitative variables that did not show normal distribution. Pearson $\chi^{2}$ test and Fisher's exact test were used to compare qualitative data. Spearman correlation analysis was used to evaluate the relationships between quantitative variables. Receiver operating characteristic (ROC) analysis was used to determine the limit values for the continuous variables that affect mediastinitis. Independent risk factors and estimated relative risks (odds ratio) were determined by logarithmic regression analysis. Linear regression analysis (backward) was used to determine the factors affecting 
the duration of VAC treatment. Statistical significance was accepted as $p<0.05$.

\section{Results}

BSA values, diabetes mellitus incidence, urea, creatinine, $\mathrm{CRP}$, sedimentation, $\mathrm{HbA}_{1 c}$ value, and preoperative hospital stay were significantly higher in mediastinitis (+) cases compared to mediastinitis $(-)$ cases $(p<0.01)$.

EF values, albumin, MPV, and HDL values of patients with mediastinitis $(+)$ were significantly lower than those with mediastinitis $(-)(p=0.001 ; p<0.01)$.

There was a statistically significant difference in the variety of surgical operations in terms of the incidence of mediastinitis $(p<0.05)$. When we compare separately to see which of these operations make a significant difference, isolated coronary artery bypass graft (CABG), isolated valve surgery, valve surgery with additional procedures, and emergency surgery were associated with a higher rate of mediastinitis $(p<0.019 ; p<0.002 ; p<0.048, p<0.028$ respectively).

Among the operative and postoperative parameters, emergency surgery rate, left internal thoracic artery (LITA) use rate, BITA use rate, TPT durations, IABP use rate, ES, fresh frozen plasma (FFP), apheresis platelet usage amounts, postoperative drainage amounts, and postoperative hospital stay were found to be statistically significantly higher in the mediastinitis group than in the control group (Table I).

The results of ROC analysis showed that preoperative laboratory values of albumin and $\mathrm{HbA}_{1 \mathrm{c}}$ had diagnostic value in predicting the development of mediastinitis after cardiac surgery (GA: 95\%, $p<0.001)$ (Table II).

As a result of regression analysis, independent risk factors for the development of mediastinitis after cardiac surgery were found to be DM, BITA use and IABP use (Table III). In the statistical analysis performed for the effect of the presence of DM on the development of mediastinitis in patients using BITA, no significant difference was found.

VAC treatment parameters were evaluated (Table IV). Parameters affecting the duration of treatment were analyzed. In univariate analysis, $\mathrm{Htc}, \mathrm{Hb}$, calcium, sedimentation, $\mathrm{HbA}_{1 \mathrm{c}}, \mathrm{HDL}$, EuroSCORE values and female gender, BITA use, inotropic use, and microbiological evaluation results were found to be independent factors affecting the duration of VAC treatment. Linear regression (backward) analysis was used to study the multivariate effects. In the regression analysis, it was found that the presence of microorganism growth at wound culture had a significant effect on the VAC treatment duration.

Regression model: VAC treatment duration (days)= $13.79+23.31 \times($ Culture $(+))$.

While there was no growth in tissue culture for 33 of the cases who received mediastinitis treatment, a single microorganism was observed in 60 and multiple microorganisms were observed in 34. Although a wide variety of microorganism growth was observed in the cases, mostly Staphylococcus species bacterial growth was detected (Figures 1, 2).
In the group treated for mediastinitis and in the logarithmic regression analysis no independent factor increasing mortality was detected.

\section{Discussion}

Modern surgical practices have significantly reduced the rate of wound infections. However, despite the improvement in surgical techniques and antimicrobial prophylaxis, there was no decrease in infection rates towards the end of the twentieth century [21]. The clinical and financial consequences of surgical site infections are quite severe for the patient, clinician, and hospital. Higher infection rates mean higher morbidity and mortality as well as higher costs for the hospital, patient, and community. Mediastinitis after cardiac surgery is a very serious complication that increases hospital costs, hospitalization time and mortality. Fortunately, mediastinitis is rare, occurring only in $1-3 \%$ of patients undergoing cardiac surgery $[2,7,9,10$, 22-24]. In our center, the incidence of mediastinitis after cardiac surgery with median sternotomy was calculated as $1.4 \%$. In a multicenter prospective study, the median duration of mediastinitis after the first surgical procedure was 20 days, and $65 \%$ of the patients were diagnosed with mediastinitis at re-admission after discharge [25]. In our study, we found these values to be similar, 18 days and $65 \%$ (82 of 127 cases).

Prevention of wound infections requires antisepsis, asepsis, perioperative antimicrobial prophylaxis, good surgical technique, preoperative identification of patients at risk and additional individual protective measures. Numerous large studies have identified several risk factors for mediastinitis [1, 2, 4-10]. These include obesity, diabetes mellitus, smoking, bilateral internal thoracic artery use, graft material, prolonged mechanical ventilation and redo surgery hospitalization period. However, the study results are often contradictory. Retrospective or prospective study design, study population size, and wound infection definitions are different. These inconsistencies make it difficult to compare findings. Demographic structures also show regional variations (race, season, etc.), which affects the results.

Since wound infections are one of the most feared complications after cardiac surgery, it is important to keep the operating room contamination at the lowest possible level. Studies in cardiac operations have shown that improving the surgical environment, refining surgical and operating room operations, and increasing awareness of the dangers of infection among staff can reduce the rate of infection [26]. It has also been shown by the infection committee that these rates can be reduced by close monitoring of hospital infections and applying necessary interventions [24].

There is a wide range of treatment when considering surgical site infections varying from non-invasive method options to those that require long hospitalization and need repeated interventions. The traditional treatment includes a broad spectrum of antibiotics with/without open dressings and/or closed irrigations. Studies compare traditional/ 
Table I. Peroperative parameters

\begin{tabular}{|c|c|c|c|c|c|}
\hline Preoperative parameters & & & Mediastinitis group & Control group & $P$-value \\
\hline Age & Mean \pm SD & [years] & $62.16 \pm 9.01$ & $60.23 \pm 10.99$ & $\mathrm{a} 0.082$ \\
\hline BSA & Mean \pm SD & {$\left[\mathrm{kg} / \mathrm{m}^{2}\right]$} & $1.94 \pm 0.16$ & $1.88 \pm 0.18$ & ${ }^{a} 0.006^{\star *}$ \\
\hline EF & Median (min.-max.) & (\%) & $55(30-65)$ & $60(30-70)$ & ${ }^{c} 0.001^{* *}$ \\
\hline Smoking & $n(\%)$ & $\begin{array}{l}\text { Yes } \\
\text { No }\end{array}$ & $\begin{array}{l}52(42.3) \\
71(57.7) \\
\end{array}$ & $\begin{array}{l}109(36.7) \\
188(63.3) \\
\end{array}$ & b0.285 \\
\hline Smoking amount & $\begin{array}{c}\text { Median } \\
\text { (min.-max.) }\end{array}$ & $\begin{array}{c}\text { [package/ } \\
\text { year] }\end{array}$ & $\begin{array}{c}12 \\
(0-70)\end{array}$ & $\begin{array}{c}15 \\
(0-150)\end{array}$ & ${ }^{c} 0.557$ \\
\hline Gender & $n(\%)$ & $\begin{array}{l}\text { Male } \\
\text { Female }\end{array}$ & $\begin{array}{l}83(65.4) \\
44(34.6)\end{array}$ & $\begin{array}{c}209(69.7) \\
91(30.3)\end{array}$ & b0.381 \\
\hline DM & $n(\%)$ & $\begin{array}{l}\text { No } \\
\text { Yes }\end{array}$ & $\begin{array}{l}48(37.8) \\
79(62.2)\end{array}$ & $\begin{array}{l}156(52.2) \\
143(47.8)\end{array}$ & $\mathrm{b}_{0} 0.007^{\star \star}$ \\
\hline Hypertension & $n(\%)$ & $\begin{array}{l}\text { No } \\
\text { Yes }\end{array}$ & $\begin{array}{l}32(25.2) \\
95(74.8)\end{array}$ & $\begin{array}{l}100(33.4) \\
199(66.6)\end{array}$ & b0.092 \\
\hline COPD & $n(\%)$ & $\begin{array}{l}\text { No } \\
\text { Yes }\end{array}$ & $\begin{array}{l}62(48.8) \\
65(51.2)\end{array}$ & $\begin{array}{l}152(50.8) \\
147(49.2)\end{array}$ & b 0.703 \\
\hline Additional disease & $n(\%)$ & $\begin{array}{l}\text { No } \\
\text { Yes }\end{array}$ & $\begin{array}{l}81(63.8) \\
46(36.2)\end{array}$ & $\begin{array}{l}216(72.2) \\
83(27.8)\end{array}$ & b0.082 \\
\hline Preoperative hospitalization duration & $\begin{array}{c}\text { Median } \\
\text { (min.-max.) }\end{array}$ & [day] & $1(1-30)$ & $1(0-31)$ & ${ }^{c} 0.001^{* *}$ \\
\hline Preoperative laboratory parameters & & & Mediastinitis group & Control group & $P$-value \\
\hline HTC & Mean \pm SD & (\%) & $38.71 \pm 5.3$ & $39.71 \pm 4.72$ & ${ }^{\mathrm{a}} 0.054$ \\
\hline $\mathrm{HB}$ & Mean \pm SD & {$[\mathrm{g} / \mathrm{dl}]$} & $12.98 \pm 2.14$ & $13.24 \pm 1.57$ & ${ }^{\mathrm{a}} 0.222$ \\
\hline WBC & Mean \pm SD & {$\left[\times 10^{9} / I\right]$} & $8.48 \pm 2.9$ & $8.49 \pm 2.37$ & a 0.954 \\
\hline Thrombocyte count & Mean \pm SD & {$\left[\times 10^{9} / 1\right]$} & $252.67 \pm 75.54$ & $266.79 \pm 84.56$ & $\mathrm{a} 0.105$ \\
\hline Urea & $\begin{array}{c}\text { Median } \\
\text { (min.-max.) }\end{array}$ & {$[\mathrm{mg} / \mathrm{dl}]$} & $\begin{array}{c}19 \\
(10-112) \\
\end{array}$ & $\begin{array}{c}16 \\
(7-60) \\
\end{array}$ & ${ }^{c} 0.001^{* *}$ \\
\hline Creatinine & $\begin{array}{c}\text { Median } \\
\text { (min.-max.) }\end{array}$ & {$[\mathrm{mg} / \mathrm{dl}]$} & $\begin{array}{c}1.0 \\
(0.4-13.2)\end{array}$ & $\begin{array}{c}0.84 \\
(0.48-4.21)\end{array}$ & ${ }^{c} 0.001^{* *}$ \\
\hline Albumin & Mean \pm SD & {$[\mathrm{g} / \mathrm{dl}]$} & $3.42 \pm 0.7$ & $4.38 \pm 0.48$ & ${ }^{\mathrm{a}} 0.001^{\star *}$ \\
\hline Calcium & Mean \pm SD & {$[\mathrm{mmol} / \mathrm{l}]$} & $9.01 \pm 0.99$ & $8.95 \pm 0.56$ & ${ }^{\mathrm{a}} 0.543$ \\
\hline MPV & Mean \pm SD & {$[\mathrm{fl}]$} & $9.03 \pm 1.3$ & $10.89 \pm 0.97$ & ${ }^{\mathrm{a}} 0.001^{\star *}$ \\
\hline CRP & $\begin{array}{c}\text { Median } \\
\text { (min.-max.) }\end{array}$ & {$[\mathrm{mg} / \mathrm{l}]$} & $\begin{array}{c}4.6 \\
(1-70) \\
\end{array}$ & $\begin{array}{c}3.19 \\
(1-99) \\
\end{array}$ & ${ }^{\mathrm{c}} 0.018^{*}$ \\
\hline Sedimentation & Mean \pm SD & {$[\mathrm{mm} / \mathrm{h}]$} & $36.03 \pm 26.26$ & $23.16 \pm 14.65$ & ${ }^{\mathrm{a}} 0.001^{\star *}$ \\
\hline $\mathrm{HbA}_{1 \mathrm{C}}$ & Mean \pm SD & (\%) & $8.03 \pm 1.87$ & $6.85 \pm 1.89$ & ${ }^{\mathrm{a}} 0.001^{\star *}$ \\
\hline Total cholesterol & Mean \pm SD & {$[\mathrm{mg} / \mathrm{dl}]$} & $187.28 \pm 66.67$ & $188.53 \pm 54.05$ & ${ }^{\mathrm{a}} 0.845$ \\
\hline LDL & Mean \pm SD & {$[\mathrm{mg} / \mathrm{dl}]$} & $114.36 \pm 43.75$ & $111.06 \pm 42.47$ & ${ }^{\mathrm{a}} 0.487$ \\
\hline HDL & Mean \pm SD & {$[\mathrm{mg} / \mathrm{dl}]$} & $40.93 \pm 11.05$ & $44.91 \pm 11.23$ & ${ }^{\mathrm{a}} 0.001^{\star *}$ \\
\hline Vitamin $B_{12}$ & $\begin{array}{c}\text { Median } \\
\text { (min.-max.) }\end{array}$ & {$[\mathrm{pg} / \mathrm{ml}]$} & $\begin{array}{c}456 \\
(176-1613)\end{array}$ & $\begin{array}{c}303 \\
(86-1299)\end{array}$ & ${ }^{\circ} 0.049^{\star}$ \\
\hline Intraoperative parameters ${ }^{\Phi}$ & & & Mediastinitis group & Control group & $P$-value \\
\hline Isolated CABG & $n(\%)$ & & 98 (77.2) & $197(65.7)$ & b0.019* \\
\hline$C A B G+$ valve surgery & $n(\%)$ & & $15(11.8)$ & $23(7.7)$ & b0.170 \\
\hline CABG + other surgery & $n(\%)$ & & $1(0.8)$ & $4(1.3)$ & $\mathrm{d}_{1.000}$ \\
\hline Isolated valve surgery & $n(\%)$ & & $5(3.9)$ & $43(14.3)$ & bo.002** \\
\hline Valve + other surgery & $n(\%)$ & & $2(1.6)$ & $18(6)$ & $\mathrm{b}_{0.048^{*}}$ \\
\hline CABG + valve + other surgery & $n(\%)$ & & $4(3.1)$ & $4(1.3)$ & $\mathrm{d}^{\mathrm{d}} 0.245$ \\
\hline Other surgery & $n(\%)$ & & $2(1.6)$ & $11(3.7)$ & ${ }^{d} 0.413$ \\
\hline EuroSCORE & $\begin{array}{c}\text { Median } \\
\text { (min.-max.) }\end{array}$ & & $\begin{array}{c}2.2 \\
(0.55-32.1)\end{array}$ & $\begin{array}{c}1.71 \\
(0.5-83.9)\end{array}$ & ${ }^{c} 0.206$ \\
\hline
\end{tabular}


Table I. Cont.

\begin{tabular}{|c|c|c|c|c|c|}
\hline Intraoperative parameters & & & Mediastinitis group & Control group & $P$-value \\
\hline Emergency surgery & $n(\%)$ & $\begin{array}{l}\text { No } \\
\text { Yes }\end{array}$ & $\begin{array}{l}112(88.2) \\
15(11.8)\end{array}$ & $\begin{array}{c}283(94.3) \\
17(5.7) \\
\end{array}$ & b0.028* \\
\hline TPT & $\begin{array}{c}\text { Median } \\
\text { (min.-max.) }\end{array}$ & [min] & $\begin{array}{c}90 \\
(0-467) \\
\end{array}$ & $\begin{array}{c}91.5 \\
(0-360) \\
\end{array}$ & ${ }^{\circ} 0.004^{\star *}$ \\
\hline ACCT & $\begin{array}{c}\text { Median } \\
\text { (min.-max.) }\end{array}$ & {$[\mathrm{min}]$} & $\begin{array}{c}48 \\
(0-244)\end{array}$ & $\begin{array}{c}49 \\
(0-1000)\end{array}$ & ${ }^{c} 0.311$ \\
\hline Redo surgery & $n(\%)$ & $\begin{array}{l}\text { No } \\
\text { Yes }\end{array}$ & $\begin{array}{c}123(96.9) \\
4(3.1)\end{array}$ & $\begin{array}{c}284(95.0) \\
15(5.0)\end{array}$ & b0.393 \\
\hline LITA use & $n(\%)$ & $\begin{array}{l}\text { No } \\
\text { Yes }\end{array}$ & $\begin{array}{c}23(18.1) \\
104(81.9)\end{array}$ & $\begin{array}{l}113(37.8) \\
186(62.2)\end{array}$ & $\mathrm{b}_{0} 0.001^{\star *}$ \\
\hline BITA use & $n(\%)$ & $\begin{array}{l}\text { No } \\
\text { Yes }\end{array}$ & $\begin{array}{c}120(94.5) \\
7(5.5)\end{array}$ & $\begin{array}{c}298(99.7) \\
1(0.3) \\
\end{array}$ & ${ }^{\mathrm{d}} 0.001^{\star \star}$ \\
\hline Bone wax use & $n(\%)$ & $\begin{array}{l}\text { No } \\
\text { Yes }\end{array}$ & $\begin{array}{l}83(65.4) \\
44(34.6)\end{array}$ & $\begin{array}{l}219(73.2) \\
80(26.8)\end{array}$ & b0.101 \\
\hline Postoperative parameters & & & Mediastinitis group & Control group & $P$-value \\
\hline IABP use & $n(\%)$ & $\begin{array}{l}\text { No } \\
\text { Yes }\end{array}$ & $\begin{array}{c}119(93.7) \\
8(6.3)\end{array}$ & $\begin{array}{c}297(99.3) \\
2(0.7)\end{array}$ & do $0.001^{\star \star}$ \\
\hline Inotropic use & $n(\%)$ & $\begin{array}{l}\text { No } \\
\text { Yes }\end{array}$ & $\begin{array}{l}80(63.0) \\
47(37.0) \\
\end{array}$ & $\begin{array}{l}169(56.5) \\
130(43.5)\end{array}$ & $\mathrm{b}_{0} 0.215$ \\
\hline Mechanical ventilation duration & $\begin{array}{c}\text { Median } \\
\text { (min.-max.) }\end{array}$ & [h] & $\begin{array}{c}12 \\
(10-2880) \\
\end{array}$ & $\begin{array}{c}12 \\
(12-960) \\
\end{array}$ & ${ }^{\circ} 0.584$ \\
\hline ICU duration & $\begin{array}{c}\text { Median } \\
\text { (min.-max.) }\end{array}$ & [h] & $\begin{array}{c}24 \\
(22-2976) \\
\end{array}$ & $\begin{array}{c}24 \\
(24-1200) \\
\end{array}$ & ${ }^{c} 0.549$ \\
\hline ES use & $\begin{array}{c}\text { Median } \\
\text { (min.-max.) }\end{array}$ & {$[\mathrm{U}]$} & $\begin{array}{c}4 \\
(0-27)\end{array}$ & $\begin{array}{c}2 \\
(0-30)\end{array}$ & ${ }^{c} 0.001^{\star *}$ \\
\hline FFP use & $\begin{array}{c}\text { Median } \\
\text { (min.-max.) }\end{array}$ & {$[U]$} & $\begin{array}{c}3 \\
(0-35)\end{array}$ & $\begin{array}{c}2 \\
(0-100)\end{array}$ & ${ }^{\circ} 0.001^{\star \star}$ \\
\hline Apheresis thrombocyte use cases & $n(\%)$ & $\begin{array}{l}\text { No } \\
\text { Yes }\end{array}$ & $\begin{array}{l}79(62.2) \\
48(37.8)\end{array}$ & $\begin{array}{c}257(86.0) \\
42(14.0)\end{array}$ & ${ }^{b} 0.001^{\star *}$ \\
\hline Total drainage & $\begin{array}{c}\text { Median } \\
\text { (min.-max.) }\end{array}$ & {$[\mathrm{ml}]$} & $\begin{array}{c}650 \\
(200-3300)\end{array}$ & $\begin{array}{c}350 \\
(100-2000)\end{array}$ & ${ }^{\circ} 0.001^{\star \star}$ \\
\hline Postoperative hospitalization duration & $\begin{array}{c}\text { Median } \\
\text { (min.-max.) }\end{array}$ & [day] & $\begin{array}{c}8 \\
(2-185)\end{array}$ & $\begin{array}{c}6 \\
(0-71)\end{array}$ & ${ }^{\circ} 0.001^{\star \star}$ \\
\hline Mortality & $n(\%)$ & $\begin{array}{l}\text { No } \\
\text { Yes }\end{array}$ & $\begin{array}{l}100(78.7) \\
27(21.3)\end{array}$ & $\begin{array}{c}286(95.3) \\
14(4.7)\end{array}$ & ${ }^{b} 0.001^{\star *}$ \\
\hline
\end{tabular}

aStudent's-t test, bPearson $\chi^{2}$ test, ${ }^{c}$ Mann-Whitney $U$ test, ${ }^{d}$ Fisher's exact test. ${ }^{*} p<0.05,{ }^{* *} p<0.01 .{ }^{\Phi}$ Valve surgery: aortic, mitral and tricuspid valve replacement and/or repair. Other surgical intervention: aortic surgery, ventricular and atrial septal defect closure, intracardiac mass excision, widening of the left ventricular outflow tract, left ventricular aneurysm repair, pulmonary embolectomy, pericardiectomy, epicardial lead placement. ACCT - aortic cross clamp time, BITA - bilateral internal thoracic artery, BSA - body surface area, CABG - coronary artery bypass graft surgery, COPD - chronic obstructive pulmonary disease, CRP - C-reactive protein, DM - diabetes mellitus, EF - ejection fraction, ES - erythrocyte suspension, FFP - fresh frozen plasma, HB - hemoglobin, HDL - high density lipoprotein, HTC - hematocrit, IABP - internal aortic balloon pump, ICU - intensive care unit, LDL - low density lipoprotein, LITA - left internal thoracic artery, MPV - mean platelet volume, PLT - platelets, TPT - total pump time, WBC - white blood cells.

conventional methods with VAC treatment in patients diagnosed with mediastinitis [12, 13, 15, 16, 27-29].

In many mediastinitis risk factor analysis studies, diabetes has been identified as an important risk factor $[1,5,7]$. DM is responsible for end organ damage and is a common disease that causes delays in wound healing. Especially uncontrolled blood sugar levels and insulin dependent DM increase the frequency of complications of the disease. In our study, we demonstrated that high values of $\mathrm{HbA}_{1 \mathrm{c}}$, which is an indicator of long-term blood sugar regulation, is a risk factor for complications, as well as a risk factor for diabetes.

Good nutritional status is essential for the process of wound healing. Ignoring the nutritional status can jeopar- dize the patient's ability to recover and then prolong the stages of wound healing. Protein deficiency contributes to reduced collagen formation and wound separation, therefore resulting in poor healing rates. Nutrition holistic assessment and early detection of malnutrition support effective wound healing. There is a strong relationship between nutritional status and serum albumin value [30, 31]. In our study, we found that albumin values were significantly low in patients with mediastinitis. However, vitamin complexes are also known to be effective in wound healing [32]. In our study, we found that high vitamin $B_{12}$ values were a significant variable in predicting mediastinitis but not an independent risk factor. In our ROC analysis which studied albumin value, we found that mediastinitis is frequently 
Table II. Parameters with diagnostic value for mediastinitis

\begin{tabular}{lccccc} 
Parameter & $\begin{array}{c}\text { Limit } \\
\text { value }\end{array}$ & $\begin{array}{c}\text { Sensitivity } \\
(\%)\end{array}$ & $\begin{array}{c}\text { Specificity } \\
(\%)\end{array}$ & $\begin{array}{c}\text { Positive } \\
\text { predictive } \\
\text { value (\%) }\end{array}$ & $\begin{array}{c}\text { Negative } \\
\text { predictive } \\
\text { value (\%) }\end{array}$ \\
$\begin{array}{l}\text { Albumin } \\
{[\mathrm{g} / \mathrm{dl}]}\end{array}$ & 4.1 & 74 & 81 & 77 & 22 \\
\hline $\mathrm{HbA}_{1 \mathrm{c}}(\%)$ & 7.65 & 70 & 81 & 55 & 23 \\
\hline
\end{tabular}

Table III. Independent risk factors for mediastinitis

\begin{tabular}{lcc} 
Risk factors & RR $(95 \% \mathrm{GA})^{*}$ & $P$-value \\
DM & $2.38(1.12-5.04)$ & 0.02 \\
\hline BITA use & $10.37(1.02-105.92)$ & 0.05 \\
\hline IABP use & $9.10(1.20-63.74)$ & 0.03 \\
\hline
\end{tabular}

${ }^{*} \mathrm{RR}$ - estimated relative risks and $95 \%$ confidence intervals shown by the odds ratio. BITA - bilateral internal thoracic artery, DM - diabetes mellitus, IABP intra-aortic balloon pump.

seen in cases below the limit value of $4.1 \mathrm{~g} / \mathrm{dl}$ and poses a risk for the development of mediastinitis.

Although good surgical technique can reduce surgical site infection, the frequency of wound infection remains the same due to the increasingly complex operation procedures. In studies conducted, most cases of mediastinitis occur in patients who have undergone CABG. The fact that CABG is the most frequently performed process in cardiac surgery also leads to this result.

Sternum nutrition is provided by the branches that the intercostal arteries and internal thoracic artery give to the sternal bone [33, 34]. Using the left and/or right internal thoracic artery as a graft during CABG operation affects sternum feeding. Boerger, Ridderstolpe, Diez et al. [2, 5-7] and a number of other studies concluded that the use of the bilateral internal thoracic artery is a risk factor for the development of mediastinitis. In our study, we found that cases with isolated CABG, isolated valve surgery and valve surgery combined with other procedures were a significant variable in predicting mediastinitis, but not an independent risk factor.
Perrault et al. [1] found that the risk of mediastinal infection increased 5.81 times in ventricular assist device and transplantation cases. In our study, we found that the use of IABP, which is an intravascular mechanical support device, was an independent risk factor for the development of mediastinitis. In both VAD and IABP systems, there is a foreign substance inside the body and an extension outside the body. This connection with the external environment may have created a risk of infection from the outside to the inside. Mortality was significantly higher in mediastinitis cases than in controls. We think that it is an expected result because the mortality is multifactorial and mediastinitis risk factors have an effect on mortality and morbidity.

In studies conducted by Sjögren et al. [14, 29], it was emphasized that risk factors for the development of mediastinitis and the mortality of conventional treatment reached $45 \%$. Although the negative effects of conventional treatment are not clear, it is believed that the progression of serious systemic infection with septic episodes due to infective treatment causes irreversible end organ damage. VAC treatment can be used as a single treatment method as well as a bridge treatment to final cure, until re-wiring.

Fuchs et al. [27] found that treatment with VAC therapy shortened hospitalization compared to conventional treatment. In their study, Petzina et al. [15] compared VAC and conventional therapy in patients with mediastinitis. They concluded that negative pressure wound therapy reduces mortality and sternal reinfection rates. Vos et al. [28] reported that intensive care follow-up was shorter and survival was longer in patients undergoing VAC treatment. They also demonstrated that VAC treatment not only reduces mortality, but also increases sternal stability, providing patient comfort by increasing patient mobilization.

Risnes et al. [12] compared VAC therapy and the conventional method in mediastinitis treatment and found that reinfection and treatment failure were more common in conventional treatment. The study of Tarzia et al. [13] showed that the average cost of patients treated with the

Table IV. VAC treatment parameters

\begin{tabular}{|c|c|c|c|}
\hline \multirow[t]{4}{*}{ Season when mediastinitis was diagnosed } & Spring & $n(\%)$ & $33(26.2)$ \\
\hline & Summer & $n(\%)$ & $38(30.2)$ \\
\hline & Autumn & $n(\%)$ & $32(25.4)$ \\
\hline & Winter & $n(\%)$ & $23(18.3)$ \\
\hline $\begin{array}{l}\text { Time between diagnosis of mediastinitis } \\
\text { and first cardiac surgery }\end{array}$ & Day & $\begin{array}{l}\text { Mean } \pm \text { SD } \\
\text { Median }\end{array}$ & $\begin{array}{c}50.37 \pm 172.45 \\
18 \\
\end{array}$ \\
\hline Number of re-explorations & $N$ & Median (min.-max.) & $\begin{array}{c}4 \\
(1-32)\end{array}$ \\
\hline VAC treatment termination time & Day & $\begin{array}{c}\text { Median } \\
(\text { min.-max.) }\end{array}$ & $\begin{array}{c}20 \\
(3-280) \\
\end{array}$ \\
\hline Frequency of re-exploration & Day & Mean \pm SD & $5.76 \pm 2.80$ \\
\hline \multirow[t]{3}{*}{ Method of sternal closure } & Unclosed (due to mortality) & $n(\%)$ & $18(14.2)$ \\
\hline & Re-wiring & $n(\%)$ & $67(52.8)$ \\
\hline & Muscle skin flap & $n(\%)$ & $42(33.1)$ \\
\hline
\end{tabular}


conventional method was significantly higher than those treated with VAC therapy.

Onan et al. [35] demonstrated that mediastinitis is a serious postoperative condition in pediatric cardiac surgery patients and cannot be treated with conventional methods, so VAC therapy is an effective way to successfully treat the condition.

Studies show the superiority of VAC treatment in terms of survival, treatment success and cost when compared to conventional methods [12, 13, 15, 16, 27-29]. In our center, we used only VAC therapy instead of traditional methods in mediastinitis treatment. The debridement and resection procedures required for the wound sites were performed under operating room conditions, followed by VAC therapy. As a result of clinical and laboratory evaluations, VAC treatment was terminated, and the wound was closed with appropriate methods such as rewiring and muscle skin flap. Unfortunately, we were unable to compare conventional methods with VAC, and this is the limitation of our study. Mediastinitis after cardiac surgery was treated with conventional methods for a long time. As a result of the developments in wound care and treatment in the last 20 years, new pages have been opened in the treatment of mediastinitis.

However, we did not find a study examining whether the factors that increase the risk of occurrence of the disease affect the treatment. The effects of the parameters collected on the mortality and duration of treatment were analyzed.

Biofilm layers can develop in all open wounds. In chronic wounds, biofilms can prevent healing, prolong healing time, and play a role in causing chronic inflammation and increasing the risk of infection [36]. Biofilm formation causes delay in recovery by excessive inflammation, nitric oxide, inflammatory cytokines, excessive and long-term stimulation of free radicals and activation of immune complexes and complement [37]. In our study, the linear regression showed that growth in tissue cultures prolongs the duration of VAC treatment. Also, in the logarithmic regression

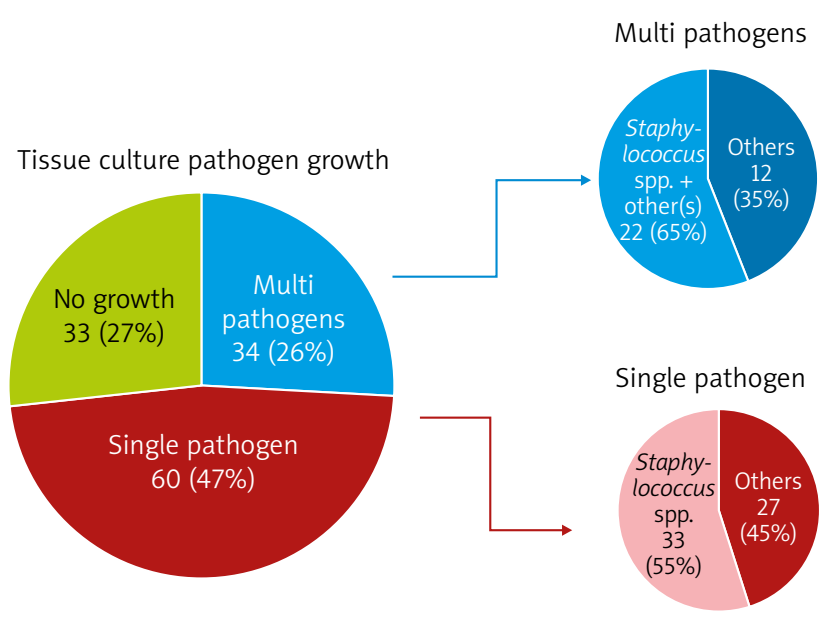

Figure 1. Microbial isolation and distribution in mediastinitis tissue culture

analysis, no independent risk factor affecting mortality was detected. Rahim et al. [38] reported that the most common microorganisms seen in chronic wounds in their study were Staphylococcus, Pseudomonas, Peptoniphilus, Enterobacter, Stenotrophomonas, Finegoldia, and Serratia. In our study, the variety of microorganism growth was similar to the literature and it was noted that positive wound tissue culture has a significant effect on the VAC treatment duration.

\section{Conclusions}

We believe that the establishment of peroperative blood glucose regulation, patient selection to use BITA grafts, and maximum attention to sepsis and antisepsis rules in patients who need mechanical support devices such as IABP, will significantly reduce the development of mediastinitis. Also, an albumin value less than $4.1 \mathrm{~g} / \mathrm{dl}$, and a $\mathrm{HbA}_{1 c}$ level higher than $7.65 \%$ are in the risk group for mediastinitis. We think that VAC therapy is a successful and safe treatment of mediastinitis and should be used more widely.

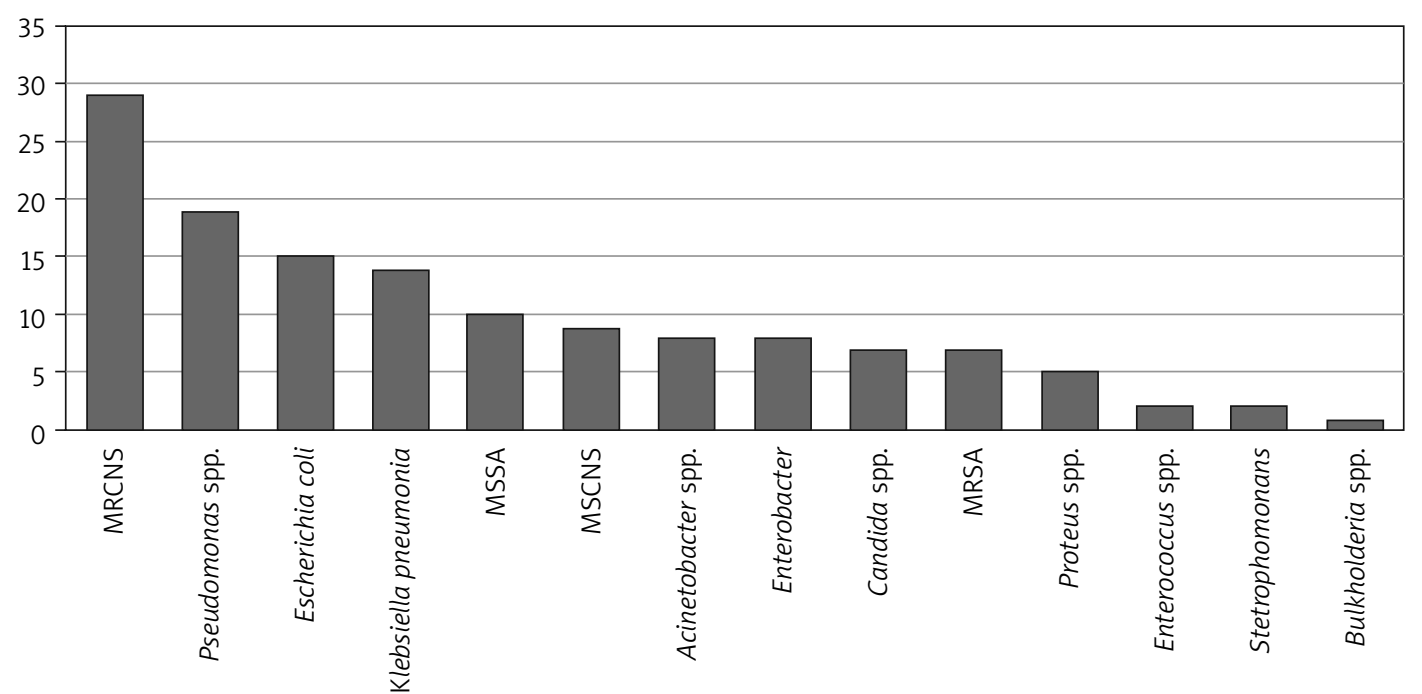

Figure 2. Count of cases with microorganism isolated 
The main goal is to reduce the incidence of the disease and prevent morbidity and mortality. Increasing the number of studies and cases included is important in order to standardize risk factors, establish and develop scoring systems, and make treatments more effective. Therefore, understanding the etiology, reducing wound infections and applying the most effective treatment require a multidisciplinary and selfless approach and effort.

\section{Disclosure}

The authors report no conflict of interest.

\section{References}

1. Perrault LP, Kirkwood KA, Chang HL, Mullen JC, Gulack BC, Argenziano M, Gelijns AC, Ghanta R, Whitson BA, Williams DL, Sledz-Joyce NM, Lima B, Greco G, Fumakia N, Rose EA, Puskas JD,, Blackstone EH, Weisel RD, Bowdish ME. A prospective multi-institutional cohort study of mediastinal infections after cardiac operations. Ann Thorac Surg 2018; 105: 461-468.

2. Ridderstolpe L, Gill H, Granfeldt H, Åhlfeldt H, Rutberg H. Superficial and deep sternal wound complications: incidence, risk factors and mortality. Eur J Cardiothorac Surg 2001; 20: 1168-1175.

3. CDC. National Healthcare Safety Network (NHSN) Patient Safety Component Manual. January 2018; 1-321. access date 01.06.2019. Available at https:// https://stacks.cdc.gov/view/cdc/50843

4. Abboud CS, Wey SB, Baltar VT. Risk factors for mediastinitis after cardiac surgery. Ann Thorac Surg 2004; 77: 676-683.

5. Borger MA, Rao V, Weisel RD, Ivanov J, Cohen G, Scully HE, David TE. Deep sternal wound infection: risk factors and outcomes. Ann Thorac Surg 1998; 65: 1050-1056.

6. Diez C, Koch D, Kuss O, Silber RE, Friedrich I, Boergermann J. Risk factors for mediastinitis after cardiac surgery - a retrospective analysis of 1700 patients. J Cardiothorac Surg 2007; 2: 23.

7. Loop FD, Lytle BW, Cosgrove DM, Mahfood S, McHenry MC, Goormastic M, Stewart RW, Golding LAR, Taylor PC. Sternal wound complications after isolated coronary artery bypass grafting: early and late mortality, morbidity, and cost of care. Ann Thorac Surg 1990; 49: 179-187.

8. Brunet F, Brusset A, Squara P, Philip Y, Abry B, Roy A. Risk factors for deep sternal wound infection after sternotomy: a prospective, multicenter study. J Thorac Cardiovasc Surg 1996; 111: 1200-1207.

9. Baskett RJF, MacDougall CE, Ross DB. Is mediastinitis a preventable complication? A 10-year review. Ann Thorac Surg 1999; 67: 462-465.

10. Ståhle E, Tammelin A, Bergström R, Hambreus A, Nyström SO, Hansson HE. Sternal wound complications - incidence, microbiology and risk factors. Eur J Cardiothorac Surg 1997; 11: 1146-1153.

11. Eklund AM, Lyytikäinen O, Klemets P, Huotari K, Anttila VJ, Werkkala KA, Valtonen M. Mediastinitis after more than 10,000 cardiac surgical procedures. Ann Thorac Surg 2006; 82: 1784-1789.

12. Risnes I, Abdelnoor M, Veel T, Svennevig JL, Lundblad R, Rynning SE. Mediastinitis after coronary artery bypass grafting: The effect of vacuum-assisted closure versus traditional closed drainage on survival and re-infection rate. Int Wound J 2014; 11: 177-182.

13. Tarzia V, Carrozzini M, Bortolussi G, Buratto E, Bejko J, Comisso M, Mescola V, Penzo V, Guarino M, De Franceschi M, Pagnin C, Castoro M, Guglielmi C, Testolin L, Bottio T, Gerosa G. Impact of vacuum-assisted closure therapy on outcomes of sternal wound dehiscence. Interact Cardiovasc Thorac Surg 2014; 19: 70-75.

14. Sjögren J, Malmsjö M, Gustafsson R, Ingemansson R. Poststernotomy mediastinitis: a review of conventional surgical treatments, vacuum-assisted closure therapy and presentation of the Lund University Hospital mediastinitis algorithm. Eur J Cardiothoracic Surg 2006; 30: 898-905.

15. Petzina R, Hoffmann J, Navasardyan A, Malmsjö M, Stamm C, Unbehaun A, Hetzer R. Negative pressure wound therapy for post-sternotomy mediastinitis reduces mortality rate and sternal re-infection rate compared to conventional treatment. Eur J Cardiothoracic Surg 2010; 38: 110-113.
16. Yu AW, Rippel RA, Smock E, Jarral OA. In patients with post-sternotomy mediastinitis is vacuum-assisted closure superior to conventional therapy? Interact Cardiovasc Thorac Surg 2013; 17: 861-865.

17. Wackenfors A, Gustafsson R, Sjögren J, Algotsson L, Ingemansson R, Malmsjö M. Blood flow responses in the peristernal thoracic wall during vacuumassisted closure therapy. Ann Thorac Surg 2005; 79: 1724-1730.

18. Morykwas MJ, Faler BJ, Pearce DJ, Argenta LC. Effects of varying levels of subatmospheric pressure on the rate of granulation tissue formation in experimental wounds in swine. Ann Plast Surg 2001; 47: 547-551.

19. Morykwas MJ, David LR, Scneider AM, Whang C, Jennings DA, Canty C, Parker D, White WL, Argenta LC. Use of subatmospheric pressure to prevent progression of partial-thickness burns in a swine model. J Burn Care Rehabil 1999; 20: 15-21.

20. Fleck T, Kickinger B, Moidl R, Waldenberger F, Wolner E, Grabenwoger M, Wisser W. Management of open chest and delayed sternal closure with the vacuum assisted closure system: preliminary experience. Interact Cardiovasc Thorac Surg 2008; 7: 797-804.

21. Robicsek F, Daugherty HK, Cook JW. The prevention and treatment of sternum separation following open heart surgery. Coll Works Cardiopulm Dis 1977; 21: 61-63.

22. Valla J, Corbineau H, Langanay T, Sevray B, Felix C, Sellin M, Le Couls H, Leguerrier A, Rioux C, Logeais Y. Mediastinitis after cardiac surgery. A 10-year evaluation (1985-1995). Ann Cardiol Angeiol 1996; 45: 369-376.

23. El Oakley RM, Wright JE. Postoperative mediastinitis: classification and management. Ann Thorac Surg 1996; 61: 1030-1036.

24. Yavuz SŞ, Tarçin Ö, Ada S, Dinçer F, Toraman S, Birbudak S, Eren E, Yekeler I. Incidence, aetiology, and control of sternal surgical site infections. J Hosp Infect 2013; 85: 206-212.

25. Perrault LP, Kirkwood KA, Chang HL, Mullen JC, Gulack BC, Argenziano M, Gelijns AC, Ghanta RK, Whitson BA, Williams DL, Sledz-Joyce NM, Lima B, Greco G, Fumakia N, Rose EA, Puskas JD, Blackstone EH, Weisel RD, Bowdish ME. A prospective multi-institutional cohort study of mediastinal infections after cardiac operations. Ann Thorac Surg 2018; 105: 461-468.

26. Ferrazzi P, Allen R, Crupi G, Reyes I, Parenzan L, Maisonnet M. Reduction of infection after cardiac surgery: a clinical trial. Ann Thorac Surg 1986; 42: 321-325.

27. Fuchs U, Zittermann A, Stuettgen B, Groening A, Minami K, Koerfer R. Clinical outcome of patients with deep sternal wound infection managed by vacuum-assisted closure compared to conventional therapy with open packing: a retrospective analysis. Ann Thorac Surg 2005; 79: 526-531.

28. Vos RJ, Yilmaz A, Sonker U, Kelder JC, Kloppenburg GTL. Vacuum-assisted closure of post-sternotomy mediastinitis as compared to open packing. Interact Cardiovasc Thorac Surg 2012; 14: 17-21.

29. Sjögren J, Gustafsson R, Nilsson J, Malmsjö M, Ingemansson R. Clinical outcome after poststernotomy mediastinitis: vacuum-assisted closure versus conventional treatment. Ann Thorac Surg 2005; 79: 2049-2055.

30. Power G, Moore Z, O'Connor T. Measurement of pH, exudate composition and temperature in wound healing: a systematic review. J Wound Care 2017; 26: 381-397.

31. Russell L. The importance of patients' nutritional status in wound healing. Br J Nurs 2001; 10 (suppl): S42, S44-9.

32. Rembe JD, Fromm-Dornieden C, Stuermer EK. Effects of vitamin B complex and vitamin C on human skin cells: is the perceived effect measurable? Adv Ski Wound Care 2018; 31: 225-233.

33. Wilcox BR, Cook AC, Anderson RH. Surgical approaches to the heart. In: Wilcox's Surgical Anatomy of the Heart. $4^{\text {th }}$ editon. Jacobs JP. Cambridge University Press 2010; 1-13.

34. Drake RL, Vogl AW, Mitchell AWM. Thorax. In: Gray's Basic Anatomy. Drake R, Vogl W, Mitchell AWM. Elsevier Churchill Livingston, Philadelphia 2012; 59-130.

35. Onan IS, Yildiz O, Tüzün B, Timur B, Haydin S. Vacuum-assisted closure for mediastinitis in pediatric cardiac surgery: a single-center experience. Artif Organs 2019; 43: 119-124.

36. Percival SL. Importance of biofilm formation in surgical infection. Br J Surg 2017; 104: e85-e94.

37. Leaper D, Assadian O, Edmiston CE. Approach to chronic wound infections. Br J Dermatol 2015; 173: 351-358.

38. Rahim K, Saleha S, Zhu X, Huo L, Basit A, Franco OL. Bacterial contribution in chronicity of wounds. Microb Ecol 2017; 73: 710-721. 